\title{
TRANSLATING CULTURE: MEDIATING CUSTOMARY LAW RELATED LANGUAGE
}

\author{
ARBEN SHALA
}

\begin{abstract}
This paper aims to outline the role of translators and interpreters as cultural mediators for international police forces during peacekeeping and peacebuilding missions in Kosovo. They were an essential source of cultural information concerning informal legal practices, folk culture, speaking style and etiquette with the parties in the procedure. These idiosyncrasies require deep understanding and are a prerequisite for producing meaningful translation.

The culture in mediation is represented in a particular way of speaking known as allegorical conversation (biseda me rrotulla). It relies on ambiguous language, on allusions, ellipsis, references to customary law resolutions, folk stories, specific and anonymous people, and traditional procedures to resolve disputes.
\end{abstract}

Keywords: public service interpreting; police language assistants; cultural mediation; customary law; folk culture

\section{Introduction}

The century-long crisis in Kosovo culminated in 1998-1999 with war and NATO's 78-day air campaign against the former Yugoslav (Serbia and Montenegro) military and industrial targets.

On June 10, 1999, the International Security Forces (KFOR) and the Federal Republic of Yugoslavia concluded a Military Technical Agreement in Kumanovo, Macedonia. The Agreement (often referred to as Kumanovo Agreement) intended to end hostilities and the humanitarian crisis and created the conditions for the deployment of international civil and security forces (S/1999/779: 2).

Kosovo became an international protectorate or trusteeship of the United Nations Interim Administration Mission in Kosovo (UNMIK) (Knudsen - Laustsen 2006: 8). UNMIK vested with "all legislative and executive powers, including the administration of the judiciary", took over responsibility for law and order, subject to a controlled transition to local authorities (Council of Europe 2005).

United Nations police officers were an integral part of the mission for approximately nine years (1999-2008). UNMIK Civilian Police (CIVPOL) consisted of police officers 
from all over the world. Initially, they maintained law and order until the Kosovo Police were ready to assume their responsibilities. The largest number of international police officers deployed was in June 2002, numbering up to 4,524 police officers (Den Heyer 2012: 93).

The deployment of international personnel gave rise to the demand for public service interpreting and translation services. International police officers depended on language personnel hired as language assistants to overcome language barriers. All police stations and police units had language assistants who interpreted and translated everything said and written throughout the legal procedures. They worked in teams in the field and in the office, always shadowing police officers.

Language assistants assisted officers in basic police tasks such as controlling traffic, foot and vehicle patrol, interviewing witnesses/victims and perpetrators, community policing, conducting checkpoints. Their services were also necessary for covert actions, arrests, house searches, and other aspects related to police work in the field and the police station. The range of tasks and duties was subject to the development and training of the local police. Moreover, language assistants took part in the selection process of the local police force (Kosovo Police Service), their training, working in joint teams and, subsequently, the monitoring stage (OSCE 2005).

After the proclamation of the independence of Kosovo in 2008, the European Union Rule of Law Mission in Kosovo (EULEX Kosovo) assumed, among others, specific executive authorities in support of law enforcement agencies. EULEX police received the same authorities as the Kosovo Police (Article 17 of Law No. 03/L-05). The United Nations delegated their authorities to the European Union as a part of what is apparently the fourth stage of peacekeeping, where the United Nations subcontract peacekeeping and peacebuilding to regional organisations (Hanhimäki 2015: 77). Inevitably, their work required more interaction with the local population before independence than after.

The EULEX police consisted of police officers from the European Union and other contributing countries (Canada, Norway, Switzerland, Turkey, and the United States). In both missions, they worked together in teams under the flag of their respective organisation. After a ten-year period, the Council of the European Union ended the judicial and executive mandate in June 2018 (S/PRST/2008/44; Article 3 of Law No. 03/L-053; Council of the EU Press Release 322/18).

English was the official language of both missions and translation and interpreting services for the parties in proceedings was conducted from English into local languages (Albanian, Bosnian, Serbian and Turkish) and vice versa (UNMIK/REG/2001/9, Chapter $4(3))$.

The need for language services gave language assistants the opportunity to take part in encounters between the international police and the local people (see Stahuljak 2010: 411). As a consequence, the international police officers and their language assistants often found themselves in unconventional situations during their interaction with the local people in the course of their work, whether in the field or in the office. Situations that recall archaic habits, etiquette and speaking style demanded specific attention to cultural mediation, as discussed in section 3.1.

Often, this turned into a difficult situation considering the sensitivity of police work and operational effectiveness. Efforts to produce meaningful statements during gaps in 
understanding subsequently raised ethical implications of competence, accuracy, and even loyalty.

\section{Methodology}

The methodology used in this paper is interdisciplinary. The personal experiences of the author working together with the international police and the Kosovo Police for over 18 years require an (auto) ethnographic approach. It provides the perspective of the author, familiar with the cultural conventions and the conceptual world of the parties to the procedure as an active participant (see Hale - Napier 2013: 85). This is combined with insights from linguistic anthropology/ ethnolinguistics when describing the language used in folk stories as a cultural resource and their use for a distinctive way of speaking as a cultural practice (see Duranti 1997: 2).

For this purpose, accounts from a two-volume book of folktales, anecdotes, short stories, and customary law resolutions (ordinal numbers in brackets) make up the corpus of this work. The stories were collected from Albanian speakers by folklore expert Anton Çetta (1920-1995) between 1966 and 1969, in the Drenica region of central Kosovo. The stories function as a source of reference for the role of customary law in the underlying meaning when a traditional form of communication is used. Communication etiquette is a refined form of social interaction.

The key terms explained in section 3.1 relate to institutions, persons entitled to implement customary law, and language used in the process of mediation. This work relates to the importance of a deep understanding of informal, albeit traditional, legal practices and folk culture for a successful mediation for the international police in Kosovo missions.

\section{Cultural mediation as a deviation from translation and interpreting}

Translation as a form of cultural mediation encompasses an "interchange between the cultures" (Bassnett 2011) and implies more than just a linguistic process. Cultural mediation as translation aims to rationalise "social production and reproduction of sense, meaning and consciousness" (O'Sullivan et al. 1994: 68). Cultural mediation takes into consideration social and cultural perspectives on specific situations or concepts and is subject to some "deviation" as Vermeer (1992: 40) notes.

Specific situations or concepts relate to a set of values and habits that often differ from those in the target language. They fall into the group categorised by Newmark (1988: 95) as cultural objects that extend to the range of ecology, material culture, social culture, organisations, customs, activities, procedures, concepts, gestures, and habits. According to Newmark (1988: 32), the main difficulties in translation are lexical, not grammatical due to 'unfindable' words. These concepts relate to lexical gaps or lacunae in translation and require the application of mediation for successful communication. 
Another difficulty in translation happens when languages operate with different maxims which "may be deliberately flouted" (Munday 2016: 155) and contain information "not linguistically implicit in the original" (Nida - Taber 1969: 199).

In Kosovo, flouted maxims have their roots in folk culture, in a form of allegorical speaking which relies on many references to specific and anonymous people and their related stories. Communication conducted by telling various anecdotes and stories intends to make a conversational implicature. This form of communication is characteristic of entire regions and of specific age groups (Çetta 1972/1990: 26; Shkurtaj 2009: 242-243). In that case, a translator or interpreter has to become a negotiator in the communication process. He has to go beyond linguistic and cultural borders and convey, "intended meaning, implied meaning, [and] presupposed meaning" (Hatim - Mason 1990: 33). Upon accomplishing this enterprise, s/he assumes the role of a linguistic anthropologist, and as Katan (1999: 7-12) observes "the level of 'contextual evaluation", is required to avoid the "loss or distortion of meaning". To achieve this, Katan contends, "he or she will need to be a specialist in negotiating understanding between cultures".

The level of negotiation, however, depends on the relationship between the interacting parties and the purpose of translational action. In legal settings, the purpose determines the mode of translational action. According to Reiß and Vermeer (1984/2014: 85-94), the priority of purpose (Skopos Theory) relies on the appropriateness of intention and purpose in a situation determined by the prevailing culture-specific norms. The latter relates to culture-specific conventions. There is room for choice, since norms can be modified or abandoned in favour of another norm. Modifications are legitimate, but they should have the same degree of conventionality or application as the modified image or word. The goal is a reasonable modification regarding a situation that leaves no room for "protest" for both the sender and the recipient. This requires, however, the assessment of the target audience and the redefinition of certain aspects subject to practical considerations.

\subsection{Customary law-related terms and procedures in mediation}

Cultural elements found challenging in translation and interpreting relate to The Code of Lekë Dukagjini, pleqërimet/pleqnitë, oda and kuvendi. These cultural elements prevail in the mind-set and rules of behaviour of people in their discourse and etiquette.

The Kanuni i Lekë Dukagjinit, translated into English by Fox (1989) as The Code of Lekë Dukagjini is a customary law that governed the areas of Kosovo and northern Albania for centuries. Collected and codified by the Franciscan priest Shtjefën Gjeçovi in 1910-1925, it was passed down through successive generations by word of mouth.

The Kanun constituted the moral basis for the customary law mediation process and consequent resolutions (pleqërimet/pleqnitë). It defined and guaranteed the independence of a person, although obedience to the rules was unquestionable because of their strict application and sanctions. Although they were ancient and brutal, they applied equally to everyone, whether rich or poor, regardless of their economic situation. According to Kanun, Article 594 "Në kandàr të vet sè i cilli peshon katerqind derhêm" (lit. Each person worth 
[lit. weighs 400 derhêms $^{1}$ on their own weigh scale (my translation)). This means that no one has the right to underestimate or offend another person, because all people are equal. However, being an equal among equals meant that one had to speak wisely, with maturity, to be a man of honour, a hospitable, brave, and honest patriot (Tirta 2004: 351-371). Failure to meet these expectations (offences against honour) often resulted in blood feuds.

The Kanun outlived Ottoman rule, which lasted for almost five centuries and their legal system. During Ottoman time, a judicial dualism was in place because as Williams (1914/1999: 16) affirms, "Turkish rule furnished no justice, and encouraged this institution, as it helped by internal enmities [blood feuds] and divisions to maintain the people in subjection". No police were present, except in towns and many blood feuds took place out in the open (Belfield 2005: ix).

The Kanun as an instrument of justice inherited for centuries seemed appropriate for the circumstances in which people lived. Customary law alone governed the lives of most Albanian people, both Catholics and Muslims. This tendency continued even after the Balkan Wars (Vickers 1998: 20; Salihu et al. 2014: xxxi). The ruling authorities under the Serb-Croat-Slovene Kingdom and Communist Yugoslavia did not interfere with the Kanun, for the same motives Williams mentions. This practice remained a common occurrence until the late 1930s (Vickers 2001: 5) and continued throughout the 1980s, until a reconciliation campaign in 1990 led by Anton Çetta (Kostovicova 2005: 117). At present, this practice has largely decreased yet it has not died out entirely. Occasionally, it appears as a relic of the past.

Pleqërimet, or in the dialect known as Pleqnitë, are stories that describe the act of mediation by describing specific real-life cases for the listener to draw an analogy. The subjects of these stories are famous pleqnars (customary law mediators).

This old practice became predominant and standard when the legal system installed by the ruling authorities failed to achieve its purpose. The installed legal system controlled and abused by the ruling authorities was considered corrupt, biased, and cruel (stories $153,438,450,451,545)$. The same applied to religious authorities believed to be at the service of the ruling system $(525,526)$. Most people considered deceiving or contriving them acceptable and convenient (453).

This explains the lack of trust in the formal legal system, an approach that extends to this day. The criteria for judging personality traits corresponded to the respect shown for the four key pillars of Kanun: honour, hospitality, comportment, and tribe. These pillars established the guiding principles in what looked like a lawless society. People had the law in their hands, but could not abuse it due to self-restraint and accountability before the Kanun (Sinani 2017). Because of this, they maintained their composure in interactions with others and used moderate and prudent vocabulary. The pillars served as a form of communal checks and balances. The language used in communication relied largely on (biseda me rrotulla) (Çetta 1972/1990: 30).

Pleqnarët e fshatit were "mediators of the village" entrusted to deal with minor conflicts at a local level (Kanun, Book 11, Article 998). If a solution was not found at a local level and if the parties (representatives and their guarantors) agreed, they could entrust the matter to an old man who mediated (pleqnar $i$ Kosoves). Generally considered a wise,

1 Old unit of measurement for weight; 400 Derhems equal to $1.28 \mathrm{~kg}$. 
impartial person with a well-established reputation, a pleqnar had long experience in administering related matters.

From Articles 992 and 994 of the Kanun, and other stories, we see that age and gender were not always strictly adhered. While mediators were usually elderly, in rare exceptions, women and youth contributed to mediation and their testimony was needed to resolve disputes $(868,881,898)$.

Once the parties reached a settlement, they could not alter their consent because of the guarantors (dorezanët) (Çetta 1972/1990: 29). In cases where either party violated the trust granted to them, the guarantors had the right to penalise the perpetrator and his family. The sanctions were the burning of houses and the expulsion of the perpetrator from the village for a certain period (836) (Salihu et al. 2014: xxxi).

In serious cases, the representatives of the tribes would call for a convention (kuvend) in their efforts to reach a resolution (Kanun, Book 148, Article 1106). In cases of serious conflicts or murders, the representatives of tribes (The Council of Elders) convened in the oda (see below) and made decisions after consideration of facts and allegations in relation to offences to honour, blood feuds, etc. $(867,869)$. Occasionally, in complicated cases, several days passed before a decision was made $(898,869)$. In such cases, parties in charge of the case were elderly people (one, two, or three for each side of the dispute). Another 6, 12, or 24 elderly people were dorëzane (guarantors) and pleq të besë (witnesses), who would take oaths in cases they considered the allegation unfounded (Çetta 1972/1990: 29).

The principles expected to be followed were fairness and impartiality. Decisions made were deemed appropriate by most pleqnars, so no one would be injured unjustly (885) (Çetta 1972/1990: 29). Grounded on Kanun as an unchallengeable traditional law, this system guaranteed accountability (429). In cases where any of the entrusted would render an unfair resolution, the men of the village and the region would call for a convention (kuvend) and all would fire their guns into the air to kill unfair and biased mediation. Then the person whose "resolution was killed" no longer had the right to mediate (Tirta 2004: 375).

The oda was the biggest and finest room in the house, often decorated with fine wooden crafts. Pleqnars convened there to hold their kuvend (convention) and make a decision. The oda had its protocol and hierarchy of principles. I zoti i shtepise or the head of the family and other influential people who had oratory skills and were esteemed for their knowledge and prudence sat by the fireplace.

The young men had no right to speak and sat closer to the door (869). The rest of the people could stay in the oda, listen to the discussion but had no right to speak unless requested (Hahn 2015: 78). The oda is a place where the convention (kuvendi) took place, an important place that played the role of a courtroom that delivered customary resolutions (pleqëritë). For other cases, it was a room used for festivities and as a place of reception of condolences when a family member passed away. In addition, it was used as a theatre where long epic songs were performed and games were played, mainly during the winter $(330,605,840,846)$, but only for men, hence the expression oda është për bur$\mathrm{ra}$ (The oda is for men [only]) (Toska - Bllaci 2011).

As a term, oda has no equivalent translation; therefore police records explained it in a footnote. The most frequent translation as "male guestroom" does not adequately convey the concept. 
Nowadays, this term has been extended to some professional organisations or associations, such as the Bar Association (Oda e Avokatëve), Notary Chamber (Oda e Noterëve).

\subsection{Language of folktales}

The language of folktales (anecdotes, short stories and customary resolutions) is the Gheg dialect. Kosovo and northern Albania speak this dialect widely but do not use it in official communication.

The narrative uses a simple language and vocabulary that supports the communicative process. The vocabulary consists of words used in everyday life, which makes an interesting narrative. However, similarly to the Kanun's language, "words are used with a sometimes staggering variety of meanings" characterised by "extreme terseness of expression" as Fox (1989: xx) notes. Occasional uses of Turkish and Serbian words, among others, refer to specific cultural references. They function as an indication of ethnic origin, occupations, or religious references generally related to ruling authorities $(120,573)$.

Therefore, the message conveyed through ambiguous language, occasionally in the form of a question-and-answer dialogue form, yields to a wise maxim (Çetta 1972/1990: 26). This form of conversation is known as an allegorical conversation (biseda me rrotulla). The narrative scenes depicted contain abundant humour, expressed by irony or subtle allusions, naïve responses, wordplay, and misunderstandings.

A person who is not familiar with this speaking style most of the time cannot detect what the implication is and may become subject to mockery (Shkurtaj 2009: 242). The communication process is not common because the words chosen are thoughtful, moderate and prudent. Communication follows a pattern (428), and intentionally avoids expressing explicit messages.

The stories convey wisdom from the past; therefore, challenging them goes against locals' moral education and their common origin and culture $(720,767)$. The focus is on insinuation, often comprised in a simple concluding sentence characterised by careful thinking. (Shkurtaj - Shopi 2018: 197-198).

According to Çetta (1972/1990: 26), the people who use this form of communication are:

"[...] gentle and calm during the conversation. They give the other their turn to speak and once the speaker has presented his arguments, then one of the people present takes his turn with: 'There was one ...', 'Once they asked one ...', 'One has said ..., and other similar formulations and serenely tells a story trying to refute the opinion of the opponent. It happens that the opponent is eloquent, and he responds with another short story and so the others get involved and the conversation continues [...]." (My translation.)

This allowed a discussion conducted in a refined, impartial language in the third person avoiding direct offence, protecting the integrity and feelings of the conversing parties. In addition, the ellipsis enables different interpretations. People who did not like the message or the insinuation given could excuse themselves by pretending they understood the story in a different way $(345,424)$.

Not all people present in the oda could understand that style of communication. Many people were afraid of having the floor because of the requirement and expectations to speak wisely and maturely, and of the fear of being mocked. The rich subtext of narratives 
and refined dialogues sought to use the power of honour (face) in search of the truth (307). There is a story or anecdote for every circumstance. When necessary, one had the liberty to create a new story (546) (Mustafa 2005: 4).

Rukiqi (2013: 166) points out several reasons for this type of speaking: the speakers addressed a more matured audience by refraining from expressing opinions openly or felt endangered by the ruling authorities. However, ideas expressed indirectly served as an education for young people because schools and books in Albanian were not allowed for many centuries (Vickers 2001: 27).

Through stories, listeners could gain a better understanding of the code of conduct, increase religious tolerance $(535,536)$ and fight against negative phenomena such as lying, cheating, stealing, greed, laziness, arrogance and other bad habits. The characters in the stories were common characters such as elders, farmers, shepherds, outlaws, and rich and poor people $(114,136,456,785)$.

\section{Mediating culture for international law enforcement authorities}

The international police, although vested with authority, remain a recipient culture. The personnel working for international and regional organisations such as the United Nations or the European Union come from different cultures and different legal systems (Šarčević 2013: 10). The situation is the same for police who bring their culture and policing models and try to apply them in the field through language assistants. In addition, they also bring their attitude towards the host culture (Faiq 2004: 1), that could translate either into a willingness to understand and try to learn about the culture and language of the host country or show various levels of ignorance.

Language assistants and local police become representatives of their respective national culture in the role of cultural experts in their joint encounters with the local population (Nakane 2014: 21). They also remain an indispensable source of cultural information about informal regional legal practices, folk culture, speaking style, and etiquette.

These idiosyncrasies seem largely conventional to local people because, as Venuti (1998: 2) points out, they are "deeply repressed in the cultural identities" and the resulting etiquette or conduct. According to Hall (1990: 223), cultural identity implies two ways of thinking or positions: one is the common shared culture and the past while the second way is the difference of "the other". In this sense, cultural identity is in contradiction to the shared culture and the past on one hand, which is inclusive and open for "the other", as long as values are not questioned but accepted per se. On the other hand, the part which exclusively resists and isolates itself from local values is seen as "the other". The latter establishes the grounds for the widely held perception of translation (especially in conflict zones) as a threat or as an "act of violence" (Venuti 2005: 177). As a result, culture influences identity and relates to conduct that suggests "a sort of underground existence in the discourse" (Bourdieu 1977/2013: 24-25).

According to Hess (2010: 10), communication is the key in establishing the first contact and in winning or losing the opportunity to obtain the cooperation of a party in the investigation process. Language assistants were the first contact with witnesses and 
suspects, and according to Matti Raatikanen (2018, personal communication), a former EULEX police officer, appropriate approaches were the key to a successful outcome.

Difficulties would arise when the local party in the procedure assumed that the international police officer was familiar with the informal speaking style and began telling a story. Therefore, during translation and interpreting for the investigation process, culture and language cannot be separated but must be carefully considered. Familiarity with these stories and knowing when to tell a specific story for a specific occasion makes one a wise man in front of other people (103).

The application of corresponding and appropriate conversation strategies and approaches may be useful for building trust between the local population and the international police. An appropriate approach saves the honour and integrity of the international police. It gives the encounter a proper course, saves time, and increases the chance of obtaining clues or causes for concerns during the contact or interviewing process. Otherwise, in cases where translation/interpreting isolates the cultural component, and works literally, soft conflicts may arise unnecessarily due to "cultural differences in value systems, social conventions, and ways of thinking” (Tang 2007: 141). That does not help the police in their efforts to establish a communication channel.

In cases where the language assistant is not familiar with the discourse, then at first, he has to become, in terms of Jakobson (1959/2000: 114), an intralingual translator/ interpreter and ask for an explanation. Once the implication is clear, s/he becomes an interlingual translator/interpreter by conveying the message. Nevertheless, this brings up implications about competence, accuracy, and loyalty - and it takes time.

Literal translation alone, ignoring the cultural component renders the translation incomplete and even misleading. Therefore, the extent of an accurate translation depends on the knowledge of the local culture and expectations thereof. The language assistant becomes a negotiator despite the requirements for verbatim or literal translation (Raatikanen 2018, personal communication). However, an accurate translation requires the application of Nord's (2006: 131), instrumental translation and interpreting carried out under target culture conditions focussing on the message, rather on literal meaning.

At first sight, a cultural expression might seem easy to translate. Nevertheless, they pose a cultural barrier due to the connotations they have with Kanun's vocabulary and procedures. Some examples of such expressions are the following: $i$ mledh pleqtë, burrat, meshlizin- lit. [he] convenes the elderly, men, council [to mediate the matter] or, me da pleqni- lit. to mediate; argat $i$ keq- lit. bad daily labourer [inciter], i ra ndore at ij - lit. he fell in his hands (surrendered to him i.e. trusted him with his life and protection was sought and expected) $(416,428,396,744,828,835,869,874,875)$.

Often references to stories become proverbial and outlive the story. Expressions such as shet dushk për gogla (363), lit. exchange dried oak leaves for oak apples, become idiomatic expressions and find a wider application for similar situations. The true meaning is derived from a story when two persons exchange something of zero value for something of the same (zero) value but both parties think they have deceived the other (Çetta 1972/1990: 21). This may explain the economy of words because, as Elsie (2016) pointed out, people in Kosovo are self-restrained; first reflect and then speak slowly. 
The long existence of such practices prevails in culture and still forms a modus operan$d i$. People who must encourage and comply with the legal system fall into these practices because they are culturally rooted.

To illustrate this, an example of circumvention of the legal system by someone expected to support the rule of law in Kosovo is the case of President Thaçi. The brother of an Albanian war victim made an allegation against him. At a later stage, the same person explained that Thaçi cleared himself (lahet, lit. wash out) of the allegation by convening 124 elderly people (Kajtazi 2017). Another example is that of the former Member of Parliament, Geci. He said that the former head of the Kosovo Liberation Army Headquarters, Syla, might clear up the allegations of the murder of two activists of the LDK (Democratic League of Kosovo) party either by law or by Kanun. If the latter, he was expected to convene 48 elderly people (Geci 2011).

Moreover, there is a tendency to attribute certain prohibited actions to Kanun and even to seek rationalization of them. Haradinaj, the former Prime Minister referred to some happy shootings that involved his subordinates as an old Albanian tradition permitted by Kanun, which is not the case (Popova - Kryeziu 2017).

This form of circumventing the authorities shows a lack of trust in the legal system. This approach inevitably challenges law enforcement authorities and efforts to install a functional judicial system. Janssens (2015: 163) incorporates Kanun, and the structures related to it in the group of non-state policing agents. The family and the Council of Elders serve as a policing system because the family serves as a security provider and a welfare system, which in turn, could interfere with investigations. That is the reason for such a low rate of reported crimes. Both police and criminals might use such a structure for their benefits. Janssens says that although there are no indications that police interacted with these structures, the encounter was unavoidable because of the work environment.

The role of a language assistant at this stage, in addition to being a constant source of cultural information, could extend to that of a guardian of language and culture. A guardian against misunderstandings in cases where the police, as Dixon (2006: 350) points out, pick up what they want to hear. In practice, however, the presence of a language assistant serves as a counterbalance between the international officer and the local people. In doing so, the interpreter remains subject to mistrust and a default target to blame. Local parties and police expect the language assistant to work for them, or at least to keep their side and be subordinate to them; the first because of national belonging and the second because of the hiring organisation and attractive salary.

The latter may bring up a problem, because as Gelles et al. (2006: 33) point out, the interpreter may risk sliding towards becoming into a surrogate interrogator. They suggest that a language assistant should appear in the subordinate role. However, the language assistants are not part of the hierarchical chain as are police and soldiers, and operating as subordinateds may bring up some interesting ethical and professional dilemmas.

According to Kelly (2000: 131-148), the intervention of the interpreter in the role of a cultural expert is indispensable to provide cultural information relevant to the case. For that, the interpreter must be qualified by the court in a particular culture but must not intervene for sympathy or belief in guilt or innocence. 
Nevertheless, the experience in the field shows that a language assistant in the role of mediator helps to negotiate and build trust. This applies to witnesses in cases of deferred justice or when the same persons are subjected to several interviews about the same incident.

In addition, it saves time and serves to break ground and establish solid trust with victims/witnesses and other concerned parties. If in doubt, the principles of humanity, neutrality, impartiality, and independence, derived from International Humanitarian Law (Barnett - Weiss 2008: 3), constitute solid guiding principles for a language assistant to follow.

\section{Conclusions}

The international police vested with an executive mandate have been present in Kosovo for approximately two decades (1999-2018). Language assistants facilitated the communication in all legal procedures.

Cultural mediation for the international police in Kosovo raised the need for a language assistant to be familiar with a characteristic form of discourse known as allegorical speaking. Allegorical speaking is a way of speaking that depends on a moderate and prudent vocabulary and related etiquette characteristic of entire regions in Kosovo. This requires the need to familiarise with it and is a prerequisite to produce a meaningful translation. It is a dying practice and closely related to the language and requirements of Kanun.

The communication process employs telling stories and references applicable to the situation under discussion to create an analogy. The stories emanating from the opinions and resolutions of customary law known as Pleqni and other folk stories accompany the discourse that occurs in the oda. The oda was a place that, among others, served as a courtroom.

Language assistants constituted an essential source of cultural information on informal legal practices, folk culture, speaking style, and related etiquette. In addition, references to customary law related language and other folk stories are sometimes expressed in idiomatic form.

The language analysed in stories relates to the folk culture still in use, although only by particular age groups. It relies on ambiguity and makes use of abundant allusions and ellipses employed to avoid direct confrontation. Despite the economy of words, the people present in the oda were expected to understand where the conversing parties "threw the stone", that is, the words (417). If not, people who are oblivious to this speaking style, including police, become a subject of laughter and mockery or even miss out the whole point of discussion.

The knowledge and appropriate translation of this speaking style saves the honour and integrity of the international police, saves time, and gives the encounter adequate direction. At the same time it increases the chances of obtaining clues, information, or causes for concerns during the contact or interviewing process.

During the process of cultural mediation, the police and other parties involved may have different expectations. This relates to the role of a language assistant finding a bal- 
ance to avoid turning into a surrogate investigator yet upholding internationally recognised humanitarian principles.

By finding a proper balance between the two, a language assistant becomes a partner in a joint effort to obtain justice and guard fundamental rights.

\section{REFERENCES}

Barnett, M. - Weiss, T. G. (2008) Humanitarianism in Question: Politics, Power, Ethics, New York: Cornell University Press.

Bassnett, S. (2011) 'The Translator as Cross-Cultural Mediator', in K. Malmkjær - K. Windle (eds.) The Oxford Handbook of Translation Studies, Oxford: Oxford University Press.

Belfield, G. (2005) 'Prince William of Wied', in D. Heaton-Armstrong - G. Belfield - B. Destani (eds.) The six month kingdom: Albania 1914, New York: I. B. Tauris, in association with the Centre for Albanian Studies.

Bourdieu, P. - Nice, R. (1977/2013) Outline of a theory of practice, Cambridge: Cambridge University Press.

Çetta, A. (1972/1990) Prozë popullore nga Drenica: 1, Prishtinë: Enti i teksteve dhe i mjeteve mësimore i Krahinës Socialiste Autonome të Kosovës. (Stories 103, 114, 120 136, 153.)

Çetta, A. (1972/1990) Prozë popullore nga Drenica: 2, Prishtinë: Enti i teksteve dhe i mjeteve mësimore i Krahinës Socialiste Autonome të Kosovës. (Stories 307, 330, 345, 363, 396, 416, 417, 424, 428, 429, $438,450,451,453,456,525,526,535,536,545,546,573,605,720,744,767,785,828,835,836,840$, $846,867,868,869,874,881,885,898,901$.

Council of Europe (2005) Report Submitted by the United Nations Interim Administration Mission in Kosovo (UNMIK) Pursuant to Article 2.2 of the Agreement between UNMIK and the Council of Europe Related to the Framework Convention for the Protection of National Minorities, 2 June 2005, ACFC (2005)003, retrieved from https://www.refworld.org/docid/47591dd62.htm

Council of the EU (2018) EULEX Kosovo: new role for the EU rule of law mission [Press release], retrieved from https://www.consilium.europa.eu/en/press/press-releases/2018/06/08/eulex-kosovo-new-role -for-the-eu-rule-of-law-mission.

Den Heyer, G. (2012) The role of civilian police in peacekeeping: 1997-2007, Washington, DC: Police Foundation.

Dixon, D. (2006) 'Regulating police interrogation', in T. Williamson Investigative Interviewing. Willan Pub.

Duranti, A. (1997) Linguistic anthropology, New York: Cambridge University Press.

Elsie, R. (2016, April 11) Shqiptarët nuk kanë ende një histori, por vetëm parulla (interview by Anisa Ymeri for 'Në Tempull' show), retrieved from http://lajmi.net/robert-elsie-shqiptaret-nuk-kane-ende-nje -histori-por-vetem-parulla.

Faiq, S. (2004) 'The Cultural Encounter in Translating from Arabic', in S. Faiq (ed.) Cultural Encounters in Arabic Translation, Clevedon: Multilingual Matters, 1-13.

Fox, L. (1989) 'Note on Translation. In Kanuni i Lekë Dukagjinit', in The Code of Lekë Dukagjini, arranged by Gjeçov, Shtjefën, Gjonlekaj Publishing Company, New York, 1989.

Geci, G. (2011, May 11) Azem Syla deshi të më vriste, retrieved from https://telegrafi.com/geci-azem-syla -deshi-te-me-vriste.

Gelles, M. G. - McFadden, R. - Borum, R. - Vossekuil, B. (2006) 'Al-Qaeda-related subjects: a law enforcement perspective', in T. Williamson (ed.) Investigative Interviewing. Willan Pub.

Gjeçov, S. (1933) Kanuni i Lekë Dukagjinit: (veper postume), Shkoder: Shtypshkroja Françeskane.

Hahn, J. G. (2015) The discovery of Albania: Travel writing and anthropology in the nineteenth century Balkans, London: Tauris.

Hale, S. B. - Napier, J. (2013) Research methods in interpreting, London: Bloomsbery Academic.

Hall, S. (1990) 'Cultural identity and diaspora', in J. Rutherford (ed.) Identity: community, culture, difference, London: Lawrence \& Wishart. 
Hanhimäki, J. M. (2008) The United Nations, New York: Oxford University Press.

Hatim, B. - Mason, I. (1990) Discourse and the Translator, London: Longman.

Hess, J. E. (2010) Interviewing \& interrogation for law enforcement.

Jakobson, R. (1959/2000) 'On linguistic aspects of translation', in L. Venuti (ed.) The Translation Studies Reader, London; New York: Routledge, 113-118.

Janssens, J. (2015) State-building in Kosovo: A plural policing perspective.

Kajtazi, V. (2017, January 18) 'Presidenti Thaçi i 'lahet me 124 pleq' Imer Imerit se nuk ka gisht në vrasjen e vëllait të tij', retrieved from http://www.insajderi.com/presidenti-thaci-lahet-124-pleq-imer-imerit-se -nuk-ka-gisht-ne-vrasjen-e-vellait-te-tij.

Katan, D. (1999) Translating Cultures: An Introduction for Translators, Interpreters and Mediators, Manchester: St. Jerome Publishing.

Kelly, A. M. (2000) 'Cultural parameters for interpreters in the courtroom', in R. Roberts - S. Carr D. Abraham - A. Dufour (eds.) The Critical Link 2: Interpreters in the Community, Amsterdam; Philadelphia: John Benjamins, 131-148.

Knudsen, T. B. - Laustsen, C. B. (2006) Kosovo between war and peace: Nationalism, peacebuilding and international trusteeship, London: Routledge.

Kostovicova, D. (2005) Kosovo: the politics of identity and space, London: Routledge.

Law No. 03/L-053 (2008) On The Jurisdiction, Case Selection and Case Allocation of EULEX Judges and Prosecutors in Kosovo, retrieved from https://www.kuvendikosoves.org/common/docs/ligjet /03-L-053\%20a.pdf.

Munday, J. (2016) Introducing translation studies, London: Routledge.

Mustafa, M. (2005) 'Recension për vëllimin Anekdota 3 të mbledhësit Salih Zogiani', in S. Zogiani (2005). Anekdota: 3. Prishtinë.

Nakane, I. (2014) Interpreter-mediated police interviews resource: A discourse-pragmatic approach. (Palgrave connect e-books.)

Newmark, P. (1988) A Text book of Translation, Hemel Hempstead: Prentice Hall.

Nida, E. A. - Taber, C. R. (1969) The practical theory and practice of translation, Leiden: E. J. Brill.

Nord, C. (2006) 'Translating as a Purposeful Activity', TEFLIN 17(2): 131-144.

OSCE Mission in Kosovo. (2005) Police Education and Development [Press release], retrieved from https://www.osce.org/kosovo/37595?download=true.

O’Sullivan, T. - Hartley, J. - Saunders, D. - Montgomery, M. - Fiske, J. (1994) Key Concepts in Communication and Cultural Studies. London: Routledge.

Popova, E. - Kryeziu, P. (2017, December 19) Kryeministri që Vendos Kanunin Para Ligjit për Veprat e Dënueshme Deri në 5 Vjet Burg, retrieved from https://kallxo.com/kryeministri-qe-vendos-kanunin -para-ligjit-per-veprat-e-denueshme-deri-ne-5-vjet-burg.

Raatikanen, M. (2018, June 05) Personal interview.

Reiß, K. - Vermeer, H. J. - Nord, C. - Dudenhöfer, M. (1984/2014) Towards a general theory of translational action, London: Routledge Taylor \& Francis Group.

Rukiqi, M. (2013) 'Përkatësia rajonale e anekdotave popullore shqiptare', in Proceedings of The XXXII International Seminar for Albanian Language, Literature and Culture, 161-167, Prishtine.

Salihu, I. - Zhitija, H. - Hasani, F. (2014) Komentari i Kodit Penal të Republikës së Kosovës, Deutsche Gesellschaft für Internationale Zusammenarbeit (GIZ) GmbH.

Šarčević, S. (2013) 'Multilingual Lawmaking and Legal (Un)Certainty in the European Union', International journal of law, language \& discourse 3 (1): 1-29.

Shkurtaj, G. (2009). Sociolinguistikë e shqipes: Nga dialektologjia te etnografia e të folurit. Tiranë: Morava

Shkurtaj, G. - Shopi, M. (2018) Gjuha, ligjërimi dhe jeta: (përmbledhje leksionesh, krestomaci dhe ushtrime sociolinguistike), Tirane: Barleti.

Sinani, Sh. (2017, May 25) Sot kanuni është "një botë e mbyllur", retrieved from https://telegrafi.com /sot-kanuni-eshte-nje-bote-e-mbyllur.

Stahuljak, Z. (2010) 'War, Translation, Transnationalism: Interpreters in and of the War (Croatia 1991-1992)', in M. Baker (ed.) Critical Readings in Translation Studies, London; New York: Routledge, 391-414.

Tang, J. (2007) 'Encounters with Cross-Cultural Conflicts in Translation', in S. M. Carr. (ed.) Translating and Interpreting Conflict, Amsterdam; New York: Rodopi, 135-147. 
Tirta, M. (2003) Etnologjia e Shqiptarëve, Tirane: Geer.

Toska, E. - Bllaci M. (2011) 7 Projekte të Konservimit të Integruar në Komunën e Junikut / 7 Integrated Conservation projects in Junik Municipality. CHwB - Trashëgimia Kulturore pa Kufij, zyra në Kosovë / CHwB - Cultural Heritage without Borders, Kosovo Office.

United Nations, General Assembly (1999, July 12) Report of the Secretary-General on the United Nations Interim Administration Mission in Kosovo, (S/1999/779), retrieved from https://www.securitycouncilreport.org/un-documents/document/kos-s1999-779.php.

United Nations, General Assembly (2008, 26 November) Statement by the President of the Security Council, (S/PRST/2008/44), retrieved from https://www.securitycouncilreport.org/un-documents /document/Kos-SPRST-2008-44.php.

UNMIK Regulation 2001/9 (2001) Constitutional Framework for Provisional Self-Government in Kosovo UNMIK/REG/2001/9, Prishtina: United Nations Interim Administration Mission in Kosovo (UNMIK), retrieved from http://www.unmikonline.org/regulations/2001/reg09-01.htm.

Venuti, L. (1998) The Scandals of Translation: Towards an Ethics of Difference, London; New York: Routledge.

Venuti, L. (2005) 'Local Contingencies: Translation and National Identities', in S. Berman and M. Wood (eds.) Nation, Language, and the Ethics of Translation, Princeton: Princeton University Press, 177-202. Vermeer, Hans (1992) 'Is translation a linguistic or a cultural process?', in M. Coulthard (ed.) Studies in Translation/Estudos in Traducao. Ilha do Desterro, Florianopolis: Edufsc, 37-49.

Vickers, M. (1998) Between Serb and Albanian: A history of Kosovo, New York: Columbia Univ. Pr. Vickers, M. (2001) The Albanians: A modern history, London: I. B. Tauris Publishers.

Williams, G. F. - Balla, S. (1914/1999) Shqiptarët [The Shkypetars], Tirane: Argeta-LMG.

\title{
RÉSUMÉ
}

Cette étude vise à décrire le rôle des traducteurs et des interprètes en tant que médiateurs culturels des forces de police internationales lors des missions de maintien et de consolidation de la paix au Kosovo. Ces derniers élaboraient une source essentielle d'informations culturelles sur les pratiques juridiques informelles, la culture populaire, la façon de parler et la politesse, résultant du style souvent rencontré par les parties lors des procédures. Ces idiosyncrasies imposent la nécessité d'une compréhension profonde et elles constituent une condition préalable à l'exécution d'une traduction faisant sens.

La culture intermédiaire se caractérise d'une manière particulière par une façon de parler connue sous le nom de conversation allégorique (biseda me rrotulla). Ce type de conversation est basé sur un langage flou, sur des allusions, des ellipses, des références coutumières au règlement des différends selon le droit coutumier (sorte d'un conseil d'arbitrage), sur des récits populaires, sur des personnes spécifiques et anonymes et des procédures traditionnelles de résolution des litiges.

Mots-clés: interprétation de service public, interprète de police, médiation culturelle, droit coutumier, culture populaire.

\author{
Arben Shala \\ Institute of Translation Studies, Faculty of Arts, Charles University \\ ben.shala@gmail.com
}

